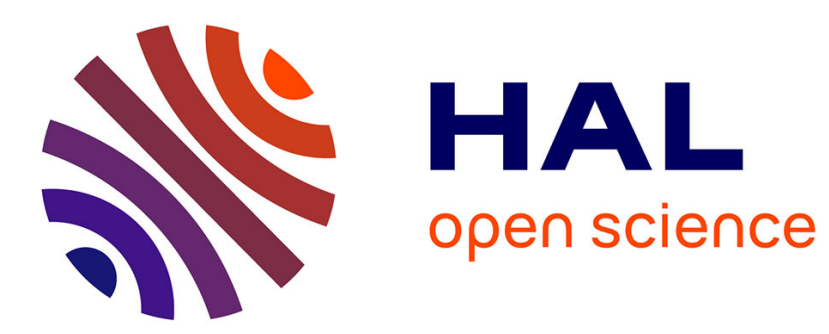

\title{
Meseritz-Obrawalde: a 'wild euthanasia' hospital of Nazi Germany
}

Susan Benedict, Tessa Chelouche

\section{To cite this version:}

Susan Benedict, Tessa Chelouche. Meseritz-Obrawalde: a 'wild euthanasia' hospital of Nazi Germany. History of Psychiatry, 2008, 19 (1), pp.68-76. 10.1177/0957154X07082567 . hal-00570909

\section{HAL Id: hal-00570909 \\ https://hal.science/hal-00570909}

Submitted on 1 Mar 2011

HAL is a multi-disciplinary open access archive for the deposit and dissemination of scientific research documents, whether they are published or not. The documents may come from teaching and research institutions in France or abroad, or from public or private research centers.
L'archive ouverte pluridisciplinaire HAL, est destinée au dépôt et à la diffusion de documents scientifiques de niveau recherche, publiés ou non, émanant des établissements d'enseignement et de recherche français ou étrangers, des laboratoires publics ou privés. 


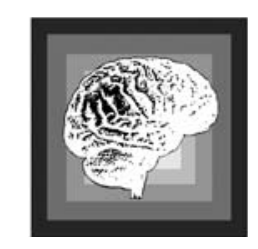

\title{
Meseritz-Obrawalde: a 'wild euthanasia' hospital of Nazi Germany
}

\author{
SUSAN BENEDICT ${ }^{\star}$ \\ Medical University of South Carolina \\ TESSA CHELOUCHE \\ University of Haifa, Israel
}

In 1939, Hitler authorized a programme of 'euthanasia' of children and adults with physical and psychiatric disorders. Initially, gas chambers were established at six psychiatric institutions in Germany and Austria. This programme was discontinued in August 1941 but the killings continued on an individual basis. Physicians selected patients who were unable to work or who required extensive care, and ordered the nurses to administer lethal doses of sedatives. Meseritz-Obrawalde was a site for 10,000 of these killings. Using documents from the trial of one of Obrawalde's physicians, Hilde Wernicke, the era of 'wild euthanasia' is described and her rationale for participating in the killings is explored.

Keywords: euthanasia; Germany; National Socialism; Nazi; psychiatry; Third Reich

As the 'science' of eugenics swept Europe and America, Hitler began his ascent to power. The convergence of these two phenomena formed the prerequisite for the extermination of people suffering from mental or physical disorders who were regarded by the state as 'useless eaters' who lived 'lives unworthy of life' (Karl Binding and Alfred Hoche, 1920; cited in Burleigh, 1997: 133). Many physicians became the enthusiastic supporters of the policies of extermination.

The operant paradigm of medical practice during this era of National Socialism was that of the physician as a 'selector' acting on behalf of the state

\footnotetext{
* Address for correspondence: Professor of Nursing, Medical University of South Carolina, 99 Jonathan Lucas Street, Charleston, SC 29401, USA. Email: Benedics@musc.edu
} 
in order to improve the health of the nation (Volksgesundheit). Having defined certain people as an underclass or a risk to the genetic or racial health of the population, medical science deemed the so-called 'inferiors' to be appropriate 'subjects' who could be selected for enforced experimentation, sterilization, incarceration and, eventually, extermination (Seidelman, 1996).

Known euphemistically as 'euthanasia', these 'medical' killings were but a part of a continuum to build a superior Aryan race by eliminating those deemed as inferior. This continuum began with the forced sterilization of people believed to have hereditary conditions and culminated with the genocide of millions of Jews, Poles, homosexuals, Gypsies and others. Physicians played an integral and essential role in the 'success' of all phases of these killings.

\section{The T-4 programme}

The so-called 'euthanasia' programme began with the killing of children with developmental or physical abnormalities and quickly expanded to a highly organized programme of murdering adult psychiatric patients. In $1939 \mathrm{Hitler}$ issued an order authorizing these killings. Six killing centres were established, beginning with one at Brandenburg in January 1940, although not all functioned concurrently. Five of these centres were at state psychiatric hospitals with the sixth, Brandenburg, being established at an abandoned prison. A multi-departmental organization was established to implement the programme which had its headquarters at Tiergartenstrasse 4 in Berlin, thus known as T-4. Patients were transferred from institutions throughout the Reich to be killed at these specialized centres where gas chambers had been constructed. By 1941 , more than 70,000 psychiatric patients had been murdered in the T-4 programme. ${ }^{1}$

It did not take long for knowledge of the killings to become widespread among the general population, and opposition arose, particularly from the Catholic Church. So the T-4 programme was officially halted in August 1941 but not the killings. Although the gas chambers were dismantled and taken, along with staff, to the Aktion Reinhard death camps of Treblinka, Sobibor and Belzec, the killing of psychiatric patients continued on an individual basis by drug overdose, starvation or even air embolus. This phase of murder was known as 'wild euthanasia'; more people were killed in this programme than in the T-4 programme (Friedlander, 1995: 151).

\section{'Wild euthanasia'}

'Wild euthanasia' was carried out at numerous hospitals throughout the Reich. One site, the state hospital Meseritz-Obrawalde, was especially active, with approximately 10,000 patients being killed by the staff (Ebbinghaus, 1987: 219). Until 1937 the hospital Obrawalde near the town of Meseritz belonged to the German state of Prussia, located in the border province of Posen/West Prussia. 
In 1938 the province of Posen/West Prussia was dissolved and Obrawalde hospital was assigned to Pomerania. Today Obrawalde is known as Obrzyce and is located in the eastern sector of Miedzyrzecz (formerly Meseritz), a part of Poland.

Obrawalde is still a functioning psychiatric hospital. Most of the origianl buildings are in use and, overall, the facility has an atmosphere not unlike a college campus. Although there is a central administration building, the units housing patients are two-storey brick buildings that function quite autonomously, each with its own staff. Because of the distance between the buildings and their self-contained organization, it is easy to understand how events taking place in one building could be completely unknown to staff and patients in another. During the time of the killings, this was essential.

In the early 1930s, Obrawalde was a very different institution from what it became 10 years later. It was a full-service general hospital with all departments headed by specialists. Working relations were good and the patients received good care. However, when Obrawalde became part of Pomerania, radical changes occurred. All the specialized departments were abolished, and Obrawalde became exclusively a psychiatric hospital. In 1939 it had approximately 900 psychiatric patients; within a year, this number increased to more than 2,000 with only three physicians, Drs Mootz, Vollheim and Wernicke, to care for them (Sagel-Grande, Fuchs and Rüter, 1979: 700). Two of these physicians Mootz and Vollheim - were over 65 years old at the time. ${ }^{2}$

The empty units of the hospital were sparsely prepared to accommodate psychiatric patients being transferred in from other institutions. The patients were extremely ill, with many being regarded as incurable. They were unable to care for themselves in any way, let alone do the work that was required of psychiatric patients of that era. The number of carers increased only slightly to help with the increased number and acuity of the patients and no additional physicians were added at all (HW).

In 1939 an order was issued to transport incurable patients to institutions further east. Physicians could exempt patients only if they were needed for work or if the patients were unable to be transported. Usually these exemptions were of short duration. The first transports were by train. The patients were accompanied by carers from Obrawalde, and the name of the destination institution was provided. Later transports were on buses when the patients were accompanied by 'strangers' (HW); the Obrawalde staff was not given the name of the destination institution. The newly emptied beds at Obrawalde were quickly filled with patients brought in from other institutions who remained for only a short time before they, too, were transported to other institutions (HW). The purpose of all of these transports was to keep patients' families from knowing their exact whereabouts, thus preventing visits and providing a cover for the patients' eventual murder.

Only one who has witnessed once the arrival of such a transport can have an idea of what we were dealing with. The patients were half-starved, often 
totally covered in their own dirt, exhausted. Many were crippled and helpless after journeys that sometimes took several days. Some died during the travel and others soon thereafter. We very often had to be on our feet day and night with only a few hours of rest in order to take care of the arrivals. Because of the crowded conditions, it was almost impossible to fight problems like lice, scabies and dysentery. The fact that we managed in spite of the overcrowding and without the possibility of isolation is due to the enormously hard work and dedication of the carers. (HW)

In 1941 Walter Grabowski, a former salesman and extremely zealous Nazi, was appointed as administrative director of Obrawalde. He implemented a number of changes in the hospital which affected the nurses and carers, and they often had to work 14 hours a day with one day off every two weeks (Sagel-Grande et al., 1979: 700). The carers on the wards were overburdened with the everincreasing number of patients and acuity of their condition. Areas previously used as living space for the patients were converted to wards, and beds were placed on top of each other. Medications and even cleaning supplies were in short supply and even the well supplying the institution's drinking water began to run dry (HW).

Grabowski was often rude and he intimidated the hospital employees. The atmosphere among the employees became one of distrust. Within a year, Obrawalde became a place of immense misery (HW). There was an enormous number of severely ill patients in addition to less incapacitated patients who were required to work in jobs supporting the institution. The farm and gardens were especially vital as the nutrition of the patients was entirely dependent on Obrawalde's own production (HW).

Wernicke described the large numbers of very ill patients who were hospitalized and how the three physicians were very overworked. They had many duties in addition to providing psychiatric care, including filling out the required government's questionnaires on each patient to register him/her with the Reicharbeitsgemeinschaft Heil- und Pflegeanstalten, the organization responsible for the euthanasia programme. Additionally, the physicians had to select patients for work in the various jobs throughout the institution. The patients' lives were valued according to their ability to work and not to require extensive care. The physicians also provided treatment of other medical conditions such as lice, dysentery, scabies and malnutrition.

\section{Participation in the killing of the patients}

Sagel-Grande et al. (1979: 700) reported that: 'Among the murdered were those who were already patients at Obrawalde, as well as patients who were transferred there from other institutions to be killed'. Dr Wernicke stated: 'In the spring of 1943 Meseritz-Obrawalde was designated to become one of the places for the killing of incurable mental patients. At that time I was to become one of the partakers in this programme. It was a special duty' (HW). Thus, Drs 
Wernicke and Mootz began their participation in the murders of the patients of Obrawalde. Mootz reviewed his patients' files and made his selection based on the reports in the files and a glance at the patient. ${ }^{3}$ Wernicke contended that she examined all her patients (HW). In addition to patients who were severely ill, those whose behaviour was more normal, but who were unable to work, were also selected. The orders to give the lethal injections were given by the physicians, but the nurses and carers were left to carry out the actual killings. It was rumoured that Grabowski 'gave premiums to Dr Wernicke, Helene Wieczorek and Amanda Ratajzcak for participating in a killing'.

In the women's portion of Obrawalde, the killings took place in buildings 1 , 3 (children's ward), 6, 8 (infectious diseases), 9 and 10. In the men's part of the hospital, most of the killings took place in building 18 (Sagel-Grande et al., 1979: 700-1). On these units, 'isolation' rooms were designed to be killing rooms. The patients to be killed were taken into the isolation room before being administered the lethal medication. Patients from units without the special 'isolation' room were transferred by the carers to units able to accommodate the procedure (p. 701). Prior to being taken to the 'isolation room', some patients were premedicated with Veronal (diethyl barbituric acid) or another sedative. Once in the room, in most cases, the killings were done with an overdose of a sedative such as Veronal or Luminal. Usually 10 tablets (or the equivalent amount of powder) were dissolved in water and given to the patient. If the patient was unable or refused to take the medication, an injection of morphine and scopolamine was given. Occasionally, an injection of air into the vein was the mode of murder (p. 701). The killing with oral medication was carried out in the following manner:

In general either the ward carer or I would sit the patient up in her bed, put an arm around her, and talk to her consolingly. So one of us would hold the patient in an upright position and the other carer would hold on to the glass with the medication. Then the patient was either able to swallow the liquid on her own or it was given to her with a spoon. If the patient was extremely restless, which also happened quite frequently, then 3 carers were needed for the procedure. At this point I would like to state that I was not present at the procedure all the time. At times it was done by the carer and me, at other times the carer and another nurse, and sometimes the nurse and I were involved - just whoever happened to be on duty that day. ${ }^{5}$

In the early days of the killings, the carers had to remove the bodies themselves. Later, as the number of killings increased, a group of male patients, 'the cemetery gang', was organized (Sagel-Grande et al., 1979: 701). Bodies were taken first to the morgue and later buried in Obrawalde's own cemetery. The patients' deaths were documented in a specially-created office of the hospital. The physicians were responsible for filling in the death certificates with fictitious but plausible causes of death that were then sent to the families of the murdered 
victims (p. 701). A common and plausible cause of death such as 'stroke' was given. Obviously, the notification of death to the relatives did not give the actual cause of death.

\section{Dr Hilde Wernicke}

Of the three physicians working at Obrawalde during the 'wild euthanasia' phase, only Wernicke was arrested and tried for her actions. Vollheim and Mootz escaped, so little is known about their histories.

Hilde Wernicke was born in 1899 in Schleswig, the daughter of an Army officer. She became a physician, graduating from medical school in Marburg, Germany, and worked as a general practitioner briefly before taking the position of assistant physician at the psychiatric institution in Regensburg. She began working at Obrawalde on 1 October 1927 as an assistant and was promoted to Assistant Medical Director in 1929. At this time, she became a civil servant. In 1933 she joined the NSDAP (Nationalsozialistische Deutsche Arbeiterpartei, the Nazi party) and in 1939 joined the Nazi Socialist Women's Party (Nationalsozialistische Frauenschaft). This she did with 'some amount of urging', according to her testimony, as 'civil servants were urged to do so as part of the war effort', even though, contradictorily in the same testimony, she acknowledged that she did 'sympathize with the "Deutschnationale Volkspartei" [The National German People's Party, a right-wing Weimar Republic party created from the union of several other political parties. It joined political coalitions with the Nazi Party]' (Michael and Doerr, 2002: 127). It is very clear from Wernicke's testimony that her political affiliations were not the basis for her practices in Obrawalde, but rather a rationalization.

As the conditions at Obrawalde deteriorated and more and more transports were arriving and leaving, Wernicke became 'disgusted with this sort of situation and attempted to leave Obrawalde'.

When I asked to leave, I was told that during wartime changes of places
were not allowed. I suffered a lot under these circumstances. So did my
colleagues, especially as rumours increased more and more that these
[transported] patients were being killed. At times, relatives informed us
about the death of a patient who had been transported 'East'. There was no
way to voice objections. Even old and trusted colleagues were done away
with when they spoke up against the action. At times it was rumoured that
a colleague had ended up in a concentration camp because he had refused
to let go of his patients. (HW)

Dr Hilde Wernicke participated in the killings of the patients from Spring 1943 until January 1945. When the Russian army arrived at Obrawalde in January 1945, Wernicke and her nurse friend, Helene Wieczorek, fled from the institution, abandoning their patients. They went to Wernicke's father's home in Wernigerode, arriving on 3 February 1945. In April, Wernicke began 
working again as a physician, continuing until her arrest on 10 August 1945. She was tried for murder in West Germany in $1945 .^{6}$

From Wernicke's testimony at the trial, one can only try to comprehend the rationale for her actions. A recurring theme in her testimony was that she considered this duty - to kill patients - a 'special one' due to the conditions of war time. She described her practice as appropriate under the circumstances, as did many other Nazi doctors in their post-war trials.

Wernicke stated that she was frightened of losing her job if she did not kill patients as directed and further said that she could easily be replaced by someone willing to do the killings. Thus, her stance was that her refusal would not only have failed to save the patients but would probably also have cost her her job. It is not known if refusal would have led to punishment, but certainly this was one of Wernicke's fears - a fear that might have been well-founded, given the description of the Director, Grabowski, as a fanatical Nazi who changed the entire atmosphere of the institution. Wernicke testified that if she had refused 'there would have been serious consequences' and that she was 'afraid for my life' (HW). She stated that she did object to the killings, but only verbally, and she did not take any action.

Wernicke stated that she never actually administered the lethal injections herself because 'as a physician I needed the trust of my patients'. ${ }^{6}$ She thereby displayed her professional knowledge of the need for the trusting relationship between physician and patient and yet, in this place of death, this trust became totally warped in deception. Although Wernicke did not give the injections, she ordered the nurses to give them. She repeatedly testified that she 'refused to perform the killing myself', contending that this exonerated her from the charge of murdering patients. Grabowski gave orders that she felt compelled to obey. This, too, allowed her yet another avenue of rationalization. She contended that she was not performing any criminal act because her action was 'a response to orders from above'. In a paradoxical argument, Wernicke stated that her obligation to carry out these orders exonerated her, yet the nurses who carried out her orders were guilty. ${ }^{6}$

Wernicke believed that she was acting in accordance with the law. She explained that Grabowski repeatedly told her that 'it was a law to do away with "unworthy lives"'. She 'worked like this for over three years' (HW) and said that any action could certainly not have continued for such a long time without legal backing. She patronizingly stated that she knew that this killing programme had to be kept secret from the general population - this further demonstrates that she realized how wrong it was.

In her testimony, Wernicke contended that she believed she was relieving the suffering of her patients by ending their lives. She used the words 'merciful death' or 'mercy injections' for the 'truly suffering malnourished, incurable patients', and said, 'They would have died soon in any case' (HW). Despite the murderous environment of the hospital, Wernicke still perceived herself to be a physician caring for patients: 'My patients were very attached to me and 
never seemed to be threatened by me' (HW). She described how Obrawalde was 'never a concentration camp' and that only 'mental' patients were admitted there. She found it her duty to 'treat' these patients who mostly arrived in an 'incurable state' and, in some instances, this treatment was to murder them. Although many of the patients were also suffering from conditions that were potentially curable such as malnutrition or scabies, no effort was made to treat those to be killed shortly after their arrival.

\section{Conclusion}

To the end of her trial, Wernicke maintained that she did not act in a criminal manner but was obeying the law of the land, that she feared punishment and that she was relieving her patients of suffering (HW). She was sentenced to death by a jury trial in Berlin on 25 March 1946 for the murder of over 600 patients. Her appeal to the court was refused. ${ }^{7}$ Wernicke and her friend, nurse Helene Wieczorek, were executed by the West German government in 1946. Wernicke was the only 'euthanasia' doctor tried before the West German courts to be executed for her deeds. Other physicians received death sentences but none were carried out (de Mildt, 1996: 97).

Wernicke was an ordinary physician and not an evil sadistic Nazi monster. She was concerned with the banal problems of daily existence of those harsh times such as potential loss of income and she identified in her own way with Germany's war effort. She killed in the name of the state. Obeying orders seemed to her to be essential, without questioning the moral stance or the consequences of this obedience. However, she totally abused the power that she had as a physician, both by ordering the subservient nurses to murder on her behalf and, of course, by the exercise of total control over her patients' lives and deaths. Even months after she left Obrawalde, and in spite of irrefutable evidence showing her to have wilfully murdered with little attempt to avoid doing so, Wernicke stated at her trial, 'I loved my patients very much, never mistreated them, never hit them. To the contrary, I always took good care in order to ease their difficult lot as much as possible' (HW).

\section{Acknowledgements}

The authors gratefully acknowledge the assistance of Traute Lafrenz Page, MD, who accompanied S. Benedict to the archives in Munich, Meseritz and Jerusalem to obtain documents and who did much of the translation of these documents. This project was funded by the National Institutes of Health, National Library of Medicine (Susan Benedict, PI, R01LM06653-01A1).

\section{Notes}

1. US NARA, Record Group 338, Microfilm Publication T-1021, Roll 18, Frame 98.

2. Statement of Hilde Wernicke, Landesgericht, Berlin, December 7, 1945; file location: Jerusalem, Yad Vashem, file number TR 10/2584 [hereafter, HW]. 
3. Testimony of Luise E., Wasserburg, Germany, June 19, 1961; file location: Staatsarchiv München, file number 33.029/2.

4. Statement of Margarete Danielson, Fägelfors, Sweden, 27 January 1961; file location: Staatsarchiv München, file number 631A/383.

5. Testimony of Luise E., Wasserburg, Germany, June 19, 1961; file location: Staatsarchiv München, file number 33.029/2.

6. Verfilmungsprotokoll Film Nr.:1, Landesarchiv Berlin B Rep. 058 Nr.: 18-22, University of Melbourne, Australia.

7. The criminal case against Hilde Wernicke and Helene Wieczorek, 24 August 1946; file location: Staatsarchiv München, file number 33/029/1.

\section{References}

Burleigh, M. (1997) Ethics and Extermination (Cambridge: Cambridge University Press).

de Mildt, D. (1996) In the Name of the People: Perpetrators of Genocide in the Reflection of their Post-War Prosecution in West Germany (The Hague: Martinus Nijhoff Publishers).

Ebbinghaus, A. (1987) Opfer und Tätterinnen (Nördlingen, Germany: Delphi Poiliti).

Friedlander, H. (1995) The Origins of Nazi Genocide (Chapel Hill, NC: The University of North Carolina Press).

Michael, R. and Doerr, K. (2002) Nazi-Deutsch Nazi-German (Westport, CT: Greenwood Press).

Sagel-Grande, I., Fuchs, H. H. and Rüter, C. F. (1979) Fustiz und NS-Verbrechen, Heil- und Pflegeanstalt Meseritz-Obrawalde, Vol. XX (Amsterdam: University Press Amsterdam).

Seidelman, W. (1996) Nuremberg lamentation: for the forgotten victims of medical science. British Medical fournal, 313, 1463-7; retrieved from: http://bmj.bmjjournals.com/cgi/ content/full/313/7070/1463. 